\title{
EFECTS OF PLASMA CORTICOSTEROID CONCENTRATION ON THE OSMOTIC THRESHOLD FOR VASOPRESSIN RELEASING IN CHAGAS' DISEASE'
}

\author{
Tatsuto Kimachi' ${ }^{1}$, Joel P. R. Veiga ${ }^{3}$ and Euclydes C. Lima-Filho ${ }^{4}$
}

\begin{abstract}
The osmotic threshold for vasopressin release was studied in normal patients $(n=7)$ and in patients with the chronic form of Chagas' disease $(n=11)$. Positive correlation between osmotic threshold and plasma cortisol concentration was obtained for the controls $\left(y_{1}=273,30+0,75 x_{i} ; r=0,78 ; P<0,05\right)$, suggesting a modulating effect of cortisol on vasopressin release. The lack of correlation between the two parameters for the chronic, chagasic patients was interpreted, on the basis of the general denervation associated with Chagas' disease, to be the result of neuronal destruction in hypothalamic and/or extrahypothalamic centers related to the secretory control of vasopressin.
\end{abstract}

Key words: Plasma Cortisol Concentration. Osmotic Threshold. Vasopressin Release. Chronic Chagas' Disease.

A possible effect of glucocorticoids on antidiuretic hormone (ADH) release has been suggested in previous studies, whereby normal concentrations of plasma cortisol were shown to be necessary for the elimination of a water overload over an appropriate period of time ${ }^{16}{ }^{15}$. In addition, studies on patients with primary or secondary adrenocortical insufficiency have indicated that increased vasopressin secretion is directly responsible for the inability to dilute urine pro-

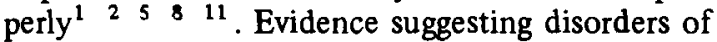
osmoregulation in patients with the chronic form of Chagas' disease has been obtained in studies of urinary concentration ${ }^{9}$ and fo the osmotic threshold for ADH secretion, whose alteration was interpreted as the consequence of changes in osmotic sensitivity of hypothalamic osmorecep-

\footnotetext{
${ }^{1}$ Research carried out in the Department of Internal Medicine, Faculty of Medicine of Ribeirão Preto, with the support of FAPESP (Grant 76/1177) and FINEP (Grant $13 / 39 / 79 / 349 / 00 / 00)$

${ }^{2}$ Department of Internal Medicine, Faculty of Medicine of Ribeirão Preto, University of São Paulo, Ribeirão Preto.

${ }^{3}$ Department of Specialized Medicine, Faculty of Health Sciences, University of Brasilia, Brasília.

${ }^{4}$ Department of Genetics and Mathematics, Faculty of Medicine of Ribeirão Preto, University of São Paulo, Ribeirão Preto.

Correspondence: JPR Veiga, Department of Specialized Medicine, Faculty of Health Sciences, University of Brasilia. Brasília. CEP 70.910.

Recebido para publicação em 15/4/1983.
}

tors $^{16}$. In addition, studies on the hypothalamus-adenohypophysis-adrenal cortex axis in chronic chagasic patients have suggested the existence of a disturbance in the control of adrenocorticotrophic hormone release, shown by wide fluctuations in plasma cortisol both under basal conditions and under various types of stimulation ${ }^{10}$.

The objective of the present investigation was to determine the possible relationship between plasma cortisol concentration and the osmotic threshold for $\mathrm{ADH}$ release in chronic patients.

\section{MATERIAL AND METHODS}

Patients - Eleven male and female adult chronic chagasic patients aged 19 to 50 were studied. Nine had the asymptomatic form of the disease, and 2 had electrocardiographic alterations showing blockage of the right branch of the Hiss bundle plus anterior left hemiblockage of the Hiss bundle and incomplete blockage of the right branch of the Hiss bundle, without previous or present cardiac insufficiency. Diagnosis of Chagas' disease was confirmed by complement fixation? and by immunofluorescence for $T$. cruzi ${ }^{5}$.

Seven male and female patients aged 19 to 46 , showing no clinical or laboratory evidence of any disease that might interfere with the results, were used as controls.

\section{Determination of the Osmotic Threshold for}


Kimachi T, Veiga JPR, Lima-Filho EC. Efects os plasma corticosteroid concentration on the osmotic threshold for vasopressin releasing in Chagas' disease. Revista da Sociedade Brasileira de Medicina Tropical 16:139-143, Jul/Set, 1983

ADH Release - After three days of adaption to hospital conditions, the patients were submitted to water overload $(20 \mathrm{ml} / \mathrm{kg})$ and infusion of $5 \%$ hypertonic saline solution. The osmotic threshold for vasopressin release was determined as previously described $^{14}$. Plasma cortisol concentration was measured during the tests by fluorimetry ${ }^{13}$ of successive blood samples. The other parameters commonly used in these tests-urine flow (V), plasma osmolarity $\left(\mathrm{P}_{\mathrm{osm}}\right)$, urinary osmolarity $\left(\mathrm{U}_{\mathrm{osm}}\right)$, urinary sodium excretion $\left(\mathrm{U}_{\mathrm{Na}} \cdot \mathrm{V}\right)$, and urinary creatinine excretion $\left(\mathrm{U}_{\mathrm{cr}} \cdot \mathrm{V}\right)$-were also measured. Osmolar clearance $\left(\mathrm{C}_{\mathrm{osm}}\right)$, free water clearance $\left(\mathrm{C}_{\mathrm{H}_{2} \mathrm{O}}\right)$ and creatinine clearance $\left(\mathrm{C}_{\mathrm{cr}}\right)$ were mea- sured by the methods currently utilized. Statistical calculations used were the standard Student's analysis and a two-variable correlation.

\section{RESULTS}

The values of osmotic threshold for ADH secretion-defined as the $P_{\text {osm }}$ level reached when a significant fall in $\mathrm{C}_{\mathrm{H}_{2} \mathrm{O}}$ was obtained without a concomitant reduction in $\mathrm{C}_{\text {osm }}$ or $\mathrm{U}_{\text {cr }}$. V-are reported in Table 1 for the controls and in Table 2 for the chagasic patients, together with plasma cortisol levels.

Table 1 - Osmotic threshold for vasopressin release and plasma cortisol concentration in control patients.

\begin{tabular}{lccc}
\hline $\begin{array}{l}\text { Patients } \\
\text { (initials) }\end{array}$ & $\begin{array}{c}\text { Age } \\
\text { (years) }\end{array}$ & $\begin{array}{c}\text { Osmotic threshold } \\
\text { mOsm } / \mathrm{kg} \mathrm{H} \mathrm{H}_{2} \mathrm{O}\end{array}$ & $\begin{array}{c}\text { Plasma cortisol } \\
\text { ug } / 100 \mathrm{ml}\end{array}$ \\
J.D.B. & 39 & 288.75 & 15.9 \\
J.F. & 19 & 288.00 & 16.9 \\
S.L. & 42 & 283.30 & 15.0 \\
L.C.M. & 23 & 282.75 & 12.2 \\
P.P. & 23 & 277.00 & 8.5 \\
R.B.F. & 46 & 289.75 & 22.4 \\
J.V.S. & 33 & 278.25 & 9.6 \\
\hline $\bar{X}$ & & & 14.36 \\
S & & 283.97 & 4.75 \\
\hline
\end{tabular}

The correlations between osmotic threshold values and plasma cortisol values at the time when the threshold was obtained were positive and significant $(r=0,78 ; P<0,05)$ for the controls. The regression of this correlation (osmotic threshold vs. plasma cortisol) was $y_{i}=273,3+0,75 x_{i}$. By using the linear coefficient variation, lines parallel to that indicated by a $\pm S_{a}$ could be drawn (Fig. 1). No correlation was obtained for the chronic chagasic patients, as shown in Figure 1.

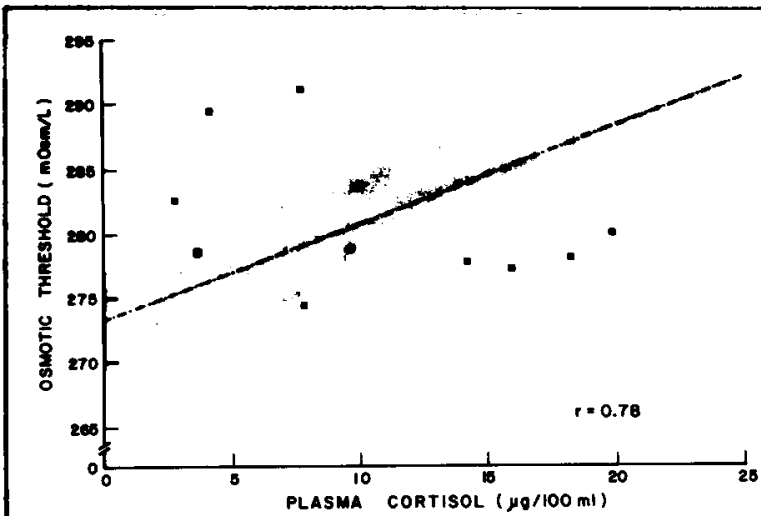

Fig. 1 - Correlation between osmotic threshold for vasopressin release and plasma cortisol concentration. The shaded zone corresponds to the limits obtained for the regression $y_{i}=273.3+0,75 x_{i}$, using $\mathrm{a} \pm \mathrm{S}_{\mathrm{a}}$, from the data for control patients. Each point represents the individual values of this correlation for the chagasic patients. 
Kimachi $T$, Veiga JPR, Lima-Filho EC. Efects os plasma corticosteroid concentration on the osmotic threshold for vasopressin releasing in Chagas' disease. Revista da Sociedade Brasileira de Medicina Tropical 16:139-143, Jul/Set, 1983

Table 2 - Osmotic threshold for vasopressin release and plasma cortisol concentration in chronic chagasic patients.

\begin{tabular}{lccc}
\hline $\begin{array}{l}\text { Patients } \\
\text { (initials) }\end{array}$ & $\begin{array}{c}\text { Age } \\
\text { (years) }\end{array}$ & $\begin{array}{c}\text { Osmotic threshold } \\
\text { mOsm/kg } \mathrm{H}_{2} \mathrm{O}\end{array}$ & $\begin{array}{c}\text { Plasma cortisol } \\
\text { ug/100 } \mathrm{ml}\end{array}$ \\
\hline A.S. & 19 & 274.50 & 7.8 \\
J.B.M. & 48 & 291.25 & 7.7 \\
J.A.C. & 32 & 282.62 & 2.7 \\
J.R.S. & 35 & 283.62 & 10.0 \\
J.R. & 45 & 277.25 & 16.0 \\
J.F.N. & 28 & 289.50 & 4.1 \\
E.T.O. & 28 & 279.75 & 18.9 \\
JP.N. & 36 & 278.75 & 3.6 \\
D.S.J. & 29 & 277.75 & 14.2 \\
R.M.S. & 43 & 278.75 & 9.6 \\
M.J.X. & 27 & 278.25 & 18.3 \\
\hline $\bar{X}$ & & 281.09 & 10.26 \\
S & & 5.22 & 5.83 \\
\hline
\end{tabular}

Glomerular filtration rate, as determined by $\mathrm{C}_{\mathrm{cr}}$, was maintained in both groups during the tests (Table 3 and Fig. 2).

Table 3 - Endogenous creatinine clearance $\left(C_{c r}\right)$ before $(A)$ and after $(B)$ ADH action.

\begin{tabular}{|c|c|c|}
\hline Patients & $\underset{\mathrm{ml} / \mathrm{min} / 1.73 \mathrm{~m}^{2}}{C_{c r}(A)}$ & $\begin{array}{c}C_{c r}(B) \\
\mathrm{ml} / \mathrm{min} / 1.73 \mathrm{~m}^{2}\end{array}$ \\
\hline J.D.B. & 120.27 & 119.91 \\
\hline J.F. & 124.87 & 124.00 \\
\hline S.L. & 109.52 & 111.17 \\
\hline L.C.M. & 126.14 & 128.00 \\
\hline P.P. & 105.96 & 102.03 \\
\hline T.B.F. & 108.49 & 107.64 \\
\hline J.V.S. & 117.00 & 115.70 \\
\hline$\overline{\mathbf{X}}$ & 116.04 & 115.49 \\
\hline$S$ & 8.09 & 9.22 \\
\hline A S. & 117.93 & 116.17 \\
\hline J.B.M. & 101.14 & 101.72 \\
\hline J.A C. & 90.38 & 91.30 \\
\hline J.R.S. & 98.77 & 99.90 \\
\hline J.R. & 108.47 & 112.74 \\
\hline J.F.N. & 103.75 & 101.37 \\
\hline E.T.O. & 144.16 & 144.26 \\
\hline J.P.N. & 95.72 & 93.65 \\
\hline D.S.J. & 110.99 & 106.81 \\
\hline R.M.S. & 120.57 & 121.10 \\
\hline M.J.X. & 118.12 & 115.00 \\
\hline$\overline{\mathbf{X}}$ & 110.00 & 109.46 \\
\hline$S$ & 14.98 & 14.95 \\
\hline
\end{tabular}

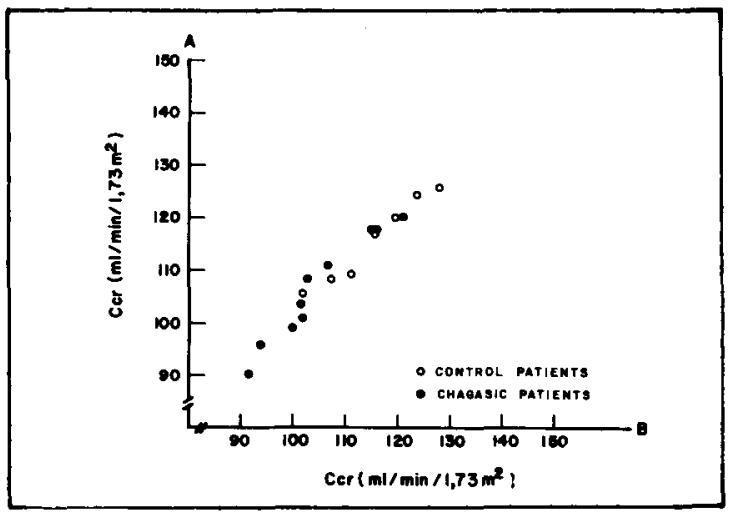

Fig. 2 - Endogenous creatinine cleareances before (A) and after (B) ADH secretion.

\section{DISCUSSION}

The positive correlation between endogenous cortisol levels and osmotic threshold for ADH release obtained for the controls suggests a modulating effect of cortisol in vasopressin secretion, possibly due to a central effect that modifies the osmotic sensitivity of hypothalamic osmoreceptors. There is the possibility, however, of a cortisol effect at the effector (kidney) level, even though glomerular filtration rate was constant before and after the antidiuretic action. Under the water overload conditions imposed on the patients the expanded volemia and the maintenance of systemic arterial pressure suggest that the correlation 
Kimachi T, Veiga JPR, Lima-Filho EC. Efects os plasma corticosteroid concentration on the osmotic threshold for vasopressin releasing in Chagas'disease. Revista da Sociedade Brasileira de Medicina Tropical 16:139-143, Jul/Set, 1983

between the parameters in question, especially the stimulus for ADH release, is due to the osmotic stimulus and not to the non-osmotic pathways that pass through peripheral baroreceptors.

Aubry et al. $^{3}$, using a methodology similar to that used in the present study, found that administration of exogenous cortisol to normal patients changed the osmotic threshold for $\mathrm{ADH}$ release and interpreted this effect to be due to the central action of cortisol Furthermore, studies on patients with primary or secondary adrenocortical insufficiency have shown a disturbance in the elimination of water overloads that might be due to permanently elevated vasopressin levels. This defect in urine dilution was corrected by administering corticosteroids ${ }^{2} 68$. Other studies on human patients with adrenal insufficiency and on adrenalectomized animals ${ }^{12}$ have demonstrated that the permanently elevated vasopressin levels obtained under these conditions may be due to stimulation of ADH secretion occurring through non-osmotic pathways, in view of the hemodynamic conditions present. Also, these studies did not reject the hypothesis of a possible glucocorticoid action at the effector level (distal tubules and collecting duct) having a permissive effect for $\mathrm{ADH}$.

The results obtained for chronic chagasic patients in the present study suggest that the action of cortisol on the osmotic sensitivity of osmoreceptors may be altered because of the wide fluctuations in plasma cortisol concentration, without any apparent relationship with the osmotic threshold. The abnormal nictemeric rhythm of cortisol secretion observed by Kimachi et al. ${ }^{10}$ in chronic chagasic patients and interpreted as a disturbance in the control of corticothophin release, explains the wide fluctuations in cortisol detected in the present study.

The lack of correlation between plasma cortisol levels and osmotic threshold for the chronic chagasic patients suggests an abnormality in the osmotic sensitivity of osmoreceptores, which do not respond to the more delicate stimuli for cortisol secretion. These alterations in osmoregulation in human chronic Chagas' disease are interpreted as the consequence of denervation of hypothalamic and/or extrahypothalamic centers related to vasopressin secretion.

\section{RESUMO}

O limiar osmótico para liberação da vasopressina foi estudado em pacientes normais (n = 7) e em pacientes com a forma crônica da moléstia de Chagas ( $n=11$ ). Verificou-se a existência de uma correlação positiva entre o limiar osmótico e a concentração plasmática do cortisol endógeno para os controles $\left(y_{i}=273,30+0,75 x_{i} ; r=0,78\right.$, $p<0,05)$, sugerindo um efeito modulador do cortisol na liberação da vasopressina. A falta de correlação entre os dois parâmetros, para os pacientes chagásicos crônicos, interpretou-se, baseando-se na desnervação geral associada com a doença de Chagas, como sendo o resultado da destruição neuronal em centros hipotalâmicos e/ou extra-hipotalâmicos relacionados com o controle secretório da vosopressina.

Palavras chaves: Concentração plasmática de cortisol, Limiar osmótico. Liberação da vasopressina. Doença de Chagas crônica.

\section{REFERENCES}

1. Aguz ZS, Goldberg M. Role of antidiuretic hormone in the abnormal water diuresis of anterior hypopituitarysm in man. Journal of Clinical Investigation 50:1478-1489, 1971.

2. Ahmed ABJ, George BC, Gonzalez-Auvert C, Dingman JF. Increased plasma arginine vasopressin in clinical adrenocortical insufficiency and its inhibition by glucosteroids. Journal of Clinical Investigation 46: 111-123, 1967.

3. Aubry RH, Nankin HR, Moses AM, Streeten DHP. Measurement of the osmotic threshold for vasopressin release in human subjects and its modification by cortisol. Journal of Clinical Endocrinology 25: 1481$-1492,1965$.

4. Boykin J, De Torrente A, Erickson A, Robertson GL, Schirier RW. Role of plasma vasopressin in impaired water excretion of glucocorticoid deficiency. Journal of Clinical Investigation 62: 738-744, 1978.

5. Camargo ME. Fluorescent antibody test for the serodiagnosis of american trypanosomiasis. Technical modification employing preserved culture forms of Trypanosoma cruzi in a slide test. Revista do Instituto de Medicina Tropical de São Paulo 8:227-234, 1966.

6. Dingman JF, Despointes R. Adrenal steroid inhibition of vasopressin release from neurohypophysis of normal subjects and patients with Addison's disease. 
Journal of Clinical Investigation 39:1851-1863, 1960.

7. Freitas JLP, Almeida JO. Nova técnica de fixação de complemento para moléstia de Chagas (reação quantitativa com antígeno gelificado de culturas de Trypanosoma cruzi. O Hospital 35: 787-800, 1949.

8. Green HR, Harrington AR, Valtin H. On the role of antidiuretic hormone in the inhibition of acute water diuresis in adrenal insufficiency and the effects of gluco and mineralocorticoids in reversing the inhibition. Journal of Clinical Investigation 49:1724-1736, 1970.

9. Kimachi T, Lomonaco DA, Veríssimo JMT. Exploração funcional do eixo hipotálamo-adeno-hipófise-cortex adrenal na forma crônica da moléstia de Chagas. Revista da Associação Médica Brasileira 20: 57 . $-66,1974$.

10. Kimachi T, Lomonaco DA, Gomes UA, Lima-Filho EC, Azevedo-Marques MM. Distúrbio do mecanismo de concentração urinária em pacientes com a forma crônica da moléstia de Chagas. Revista do Instituto de Medicina Tropical de São Paulo 20:6-14, 1978.

11. Kleeman CR, Czaczkes JW, Cutler R. Mechanism of impaired water excretion in adrenal and pituitary in- sufficiency. IV. Antidiuretic hormone in primary and secondary adrenal insufficiency. Journal of Clinical Investigation 43: 1641-1648, 1964.

12. Linas SL, Berl T, Robertson GL, Aisenbrey GA, Schirier RW, Anderson RJ. Role of vasopressin in the impaired water excretion of glucocorticoid deficiency. Kidney International 18:58-67, 1980.

13. Mattingly D. A simple fluorimetric method for the estimation of free 11-hydroxycorticoids in human plasma. Journal of Clinical Pathology 15:374-379, 1962.

14. Moses AM, Miller M. Osmotic threshold for vasopressin release as determined by saline infusion and by dehydration. Neuroendocrinology 7:219-226, 1971.

15. Raiz LE, McNecley WF, Saxon L, Rosembaun JD. The effects of cortisone and hydrocortisone on water diuresis and renal function in man. Journal of Clinical Investigation 36: 767-779, 1957.

16. Veiga JPR. Limiar osmótico para liberação do hormônio antidiurético em pacientes com a forma crônica da moléstia de Chagas Dissertação de Mestrado, Universidade de São Paulo, Faculdade de Medicina de Ribeirão Preto, 1979. 